\title{
The Role of English Songs in Saudi Students' Self-Learning of English
}

\author{
Omar Jabak \\ Department of Foreign Languages, College of Arts and Sciences, University of Nizwa, Oman
}

\begin{abstract}
The present study aimed to explore the role of English songs in Saudi students' self-learning of English as a foreign language. The study employed one data collection tool which was an online questionnaire. The questionnaire was completed by 38 Saudi students at the Community College of King Saud University in the second semester of the academic year 2020. The examination and analysis of the data showed that listening to English songs motivated the Saudi students to learn English in a self-study mode, augmented their English vocabulary, improved their speaking skill and developed their spelling or writing skill to a considerable extent. It is, therefore, recommended that more large-scale quantitative or qualitative studies on the role of English songs in Saudi students' self-learning of English as a foreign language be conducted to confirm the findings of the present study, challenge them or yield new ones.
\end{abstract}

Index Terms —English songs, self-learning, English language skills, Saudi students, motivation

\section{INTRODUCTION}

The advent of technology coupled with the Internet has provided a great opportunity for students of English as a foreign language all over the world to learn English on their own through making use of technology and the Internet both separately and combined together. The new generation, born into this marriage of technology and the Internet, has always been referred to as the digital natives (Kurt et al. 2013; Wu, C.L 2015; Yong et al. 2014). The spread of English songs has also increased due to the availability of various channels and applications which help broadcast and spread these songs. Thanks to smart technology, students, the whole world over, have easy access to such songs via their smartphones, tablets, laptops and other electronic devices (Sad et al., 2014). With the availability and accessibility of YouTube channels and other social medial applications, learning English as a foreign language in an autonomous way or in a self-learning mode has become more common than before.

English songs are very common these days all over the world, especially among teenagers (Tarrant, 2002) as teenagers seem to have a natural tendency to listen to music, enjoy it and interact with it in a variety of ways. In fact, such songs can be looked at as a universal aspect of the English language which can assist learners of English as a foreign language in improving a range of English language skills (Alherbi, 2015; Fras et al., 2015; Ilham, 2009; Israel, 2013; Keskin, 2011; Komur et al., 2005; Murray, 2005; Siskova, 2008). Almost everywhere one goes, he/she hears contemporary English songs. It also seems that most English singers themselves are teenagers which most likely accounts for the wide spread of these songs and their popularity with teenagers in particular in different parts of the world. Given the fact that most college students are teenagers, they are very likely to listen to English songs while playing games online, studying or passing their time privately. Saudi college students are no exception in this regard; they listen to English songs and try to memorize them, too (Holbah, 2015).

From personal observation, the researcher noticed that his teenage children as well as some of his students listen to English songs quite often. He asked them if listening to English songs was useful at all. To his surprise, their responses were all positive, and the majority of them said that their English also improved substantially. The researcher, then, decided to carry out a small-scale qualitative study to further investigate the role which English songs play in Saudi students' self-learning of English as a foreign language. To that effect, he chose a group of his students as participants in this study and designed an online questionnaire the purpose of which was to find out whether or not listening to English songs contributes positively or negatively to the students' self-learning of English as a foreign language. It would also be interesting to learn about the skills which listening to English songs improves, and whether or not listening to English songs is of any use at all to the Saudi college students surveyed.

The significance of the present study lies in the fact that such a topic has not been approached before in Saudi Arabia within the context of the self-learning mode of English as a foreign language. The present study is also important because there has not been any such study in a Saudi setting to the best of the researcher's knowledge and based on a thorough review of the relevant literature available on this topic to date conducted by the researcher. Moreover, the researcher could not find any linguistic or language-related theory that supports the use of songs in students' selflearning of a foreign language in general. The lack of theoretical support for such a study makes the findings arrived at important to the formation or development of a theory or a theoretical framework.

\section{A. The Objectives of the Study}


Since research on the role of English songs in Saudi students' self-learning of English as a foreign language has not been done to the best of the researcher's knowledge and search, the present study seeks to bridge this gap and provide new insights into the effectiveness of listening to English songs in improving some Saudi students' self-learning of English as a foreign language. With this general aim in mind, the present study aims to achieve the following objectives:

1- To find out whether English songs have any influence on Saudi students' self-learning of English;

2- To identify the skills which English songs improve in Saudi students' self-learning of English;

3- To provide the field of teaching English as a foreign language (TEFL / EFL) with insights into self-learning of English as a foreign language through English songs.

\section{B. The Statement of the Problem}

The present research study seeks to find answers to the following two questions:

1. Do English songs have any effect on Saudi students' self-learning of English as a foreign language?

2. What are the skills which English songs develop in Saudi students' self-learning of English?

\section{Literature Review}

Based on a rigorous review of the literature available on the topic of the present study conducted by the researcher, there has been no study dealing with the topic of the role of English songs in students' self-learning of English as a foreign language to date. However, there have been some studies on using English songs in teaching English as a foreign language in class or in improving students' English language skills. The researcher included some of the most recent studies available on topics similar to the topic of the present study. This section will shed light on previous studies which the researcher has found on using English songs in teaching English as a foreign language in non-Saudi and Saudi contexts and establish some links between them and the present study in terms of the topic, the scope, the research design, the data collection tools, the participants and finally the findings.

To begin with, Vishnevskaia and Zhou (2019) carried out a study to explore the effect of using English songs as a tool for teaching English as foreign language in China by a non-native English teacher. The above study is a reflective account of the researchers' teaching experience as non-native English teachers of English in China. The researchers drew upon their experience and some scholarly studies on topics similar to their topic to highlight the positive effects of using songs as an educational tool to help English teachers teach English in an enjoyable and interactive way. The main finding of the above study was that using English songs in an EFL classroom would strengthen the relationship between students and EFL teachers. Another important finding which the above study arrived at was that music and English songs would make students behave better in class and relax, especially after long periods of hard work in other courses. Finally, the study showed that students would learn new vocabulary and grammatical structures and improve their pronunciation skill if they listened to English songs in class. Although the above study based its findings on somehow subjective perspectives of the researchers, the present study seems to be in line with the finding that listening to English songs improves students' vocabulary and speaking skills. The scope of the above study is also different from the scope of the present study as the above study focused on EFL teachers' use of English songs as an educational tool to motivate students to learn English in class, while the present study sought to explore the effect of English songs on students' self-learning of English outside class.

Hindeme et al. (2018) conducted a study on the roles of English songs in teaching English to high school students. The researchers designed two questionnaires to help them to collect data for their study. One questionnaire targeted the perceptions of the English teachers in Beninese high schools with regard to the use of English songs in teaching English to their students in class. The other questionnaire was given to the high school students to crosscheck the responses of the English teachers to the questions in the first questionnaire. The findings of the study revealed that EFL teachers in Benin Republic needed training in the use of English songs in EFL classes. The study also found that EFL teachers should be involved in selecting appropriate songs for their students, and students could be involved in the selection process, too. The study also showed that when students memorized English songs, they not only learned new vocabulary, but they also learned new things about the culture of the English language. Based on the above findings, the study recommended that EFL teachers take advantage of English songs to teach grammar, vocabulary and other language-related aspects. The above study and the present study both utilized the same data collection tool which was a questionnaire. While the above study aimed at exploring the role of English songs as used by EFL teachers in class, the present study focused on students' self-study of English outside class through English songs via self-learning or autonomous learning without the help of EFL teachers. Despite the difference in scope between the above study and the present study, some similar findings could emerge especially with regard to the English language skills honed by EFL students' listening to English songs whether in class or outside class.

In an Iranian study on the effects of teachers' use of English songs on EFL learners' learning of English vocabulary, Javadi-Safa (2018) employed two groups of participants; an experimental group and a control one. The researcher had the experimental group listen to English songs in class, while the control group only read the words of the songs without listening to them. The general finding of the study showed that the vocabulary of the experimental group increased noticeably due to listening to, and interacting with, the English songs in comparison to the vocabulary of the control group which did not improve as much. The participants in the above study were similar to the participants in the present study in terms of gender as they were all male teenage students learning English as a foreign language. The general 
finding of the above study that listening to English songs contributes to augmenting EFL students' vocabulary is in line with one of the findings of the present study pertaining to developing EFL students' vocabulary skill. One major difference between the above study and the present study lies in the mode of learning with regard to English as a foreign language. The present study focused on students' self-learning of English through listening to English songs in informal learning settings other than a formal classroom setting, while the above study exposed EFL students to English songs in class or in a formal educational setting.

Dzanic et al. (2016) carried out a study in which they sought to identify the effects of English songs on young learners from Bosnia and Herzegovina and their motivation to learn English. The researchers used three English songs for children and taught them to 28 second grade (7-8 years of age) pupils. In addition, the researchers used three types of tests (pre-tests, post-tests and delayed tests) and a questionnaire as the main data collection tools. The findings of their study revealed that the selected English songs had a positive effect on the pupils' learning of English vocabulary and that the pupils themselves were further motivated to both learn English and enjoy it. Despite the similarity between the above study and the present study in terms of the general finding on the positive effect of English songs on improving EFL students' English vocabulary, there are substantial differences as well. The above study employed very young children as its participants or respondents, whereas the present study used college students. Besides, the above study exposed the participants in the study to three English songs in class which were designed for children, whereas the present study did not specify any English songs or limit their number and sought to measure the effect of English songs on the participants' self-learning of English as a foreign language outside class.

In a Polish study carried out by Kusnierek (2016), the researcher aimed to identify the role of music and English songs in teaching English vocabulary to primary school boys and girls. The researcher used a questionnaire as well as informal pre-tests and post-tests to collect data and achieve the general objective of the study. The findings revealed that the majority of the students liked to listen to music and English songs. Besides, most of the students liked to listen to English songs in class and thought that English songs were a useful tool which teachers could use to teach English vocabulary. Additionally, most of the students said they enjoyed listening to English songs at home as well. Although the topic of, and participants in, the above study were different from the topic of, and participants in, the present study, the general conclusion that listening to English songs contributes to improving EFL students' English is a significant denominator. If the researcher of the above study took into account gender as an important variable in the study, there could have been some other important findings which could have added new insights into the topic of the study and opened the door to further research on gender differences in the effects of English songs on EFL learners.

In a study by Sargsyan et al. (2016) on the use of English outside classrooms, Armenian EFL learners were surveyed and interviewed with an eye to exploring the ways in which Armenian students use their knowledge of English outside classrooms. The researchers employed 38 students, distributed a questionnaire among them and conducted in-depth interviews with them in order to collect data for their study. The study came to the conclusion that the students used English outside class quite often while listening to English songs, watching movies and surfing the net. The topic and scope were among the differences between the above study and the present study. Another important difference between the above study and the present one had to do with participants. While the above study used girls and boys at different ages, the present study employed male students only, most of whom were 19 years old. Although the above study found out that the EFL students used English to listen to English songs among other recreational activities, it did not seek to find out if listening to English songs had any effect on the students' learning of English outside class. However, the above study, like the present study, used a questionnaire to help collect data from the participating students in the study.

There was a French study conducted by Taffoli et al. (2014) on whether or not listening to English songs helped French students learn English. The researchers designed a questionnaire and gave it to 227 French students registered in a non-specialist English course. In this respect, the study is similar to the present study in terms of the data collection tool. Another aspect of similarity is the sample of the population surveyed. In the above study and the present study, the participants were college students not taking English as a major. This might make some of the findings of both studies somehow similar. In general, the above-mentioned study came to the conclusion that listening to English songs in the students' free time could be regarded as an informal way of learning outside class. The researchers of the above study believed that "English language music is an important part of learner identity and can potentially contribute to the incidental acquisition of English" (p. 205). One important difference between the above study and the present study was in the number of participants; the above study had 227 participants, while the present study had only 38 participants.

Israel (2013) carried out a study on the enhancement of learning English for South African high school students through listening to music and English songs. The researcher used a case study in which her eleventh-grade students were the sample of her study. She was an English language teacher in charge of teaching English literature, precisely poetry, to those students and decided to test her own hypothesis that students would be motivated to learn English through listening to famous English lyrics and songs. The teacher researcher came to the conclusion that English songs could be a very good opportunity for EFL teachers to motivate their students to both learn English and enjoy this learning experience. She also found out that her students did really like the learning experience and were motivated to learn English. The general finding of the above study is in line with the general premise of the present study that English songs do contribute to developing students' English language skills. However, like most other studies reviewed 
in this section, the above study focused on teachers' introduction of English songs to their English classes as a teaching tool or method, whereas the present study focused on students' use of English songs as a self-learning technique employed by students outside class.

In another study conducted in Turkey by Komur et al. (2005), 16 English primary teachers along with 393 4th and 5th grade pupils were asked about the effectiveness of using English songs in improving pupils' learning of English. The researchers developed a questionnaire and administered it to both teachers and pupils with an eye to finding out if incorporating English songs into classroom activities would motivate the pupils to learn English and expand their vocabulary. Despite the fact that the pupils were very young in age, about 10 and 11 years old, the researchers believed that their responses to the questionnaire were, to some extent, meaningful and significant as they and their English teachers "stressed the importance of the contributions of music to vocabulary teaching" (p. 118). Despite the fact that the above study and the present study both used a questionnaire as the main data collection tool, the present study focused on the self-learning mode of English as a foreign language by students which takes place outside college. Besides, the participants in the present study were all adult students, unlike the majority of the participants in the above study who were very young children and whose responses might not be as conscious or well-informed as the responses of adult students which would definitely yield different findings.

As far as the Saudi context is concerned, the researcher found one Saudi study whose topic is somehow close to the topic of the present study. The study was conducted by Almutairi et al. (2016) on the attitudes of EFL teachers towards using English songs for teaching oral skills to Saudi primary school students. The researchers used a questionnaire to survey the attitudes of 89 EFL teachers. The findings of the study showed that most of the teachers realized the educational value of using songs in teaching English oral skills to Saudi primary school students, but unfortunately, they do not use English songs in class because of the religious and cultural beliefs of the country according to the researchers. The above study examined the attitudes of EFL teachers in Saudi Arabia towards the use of English songs to improve the young students' oral skills, while the present study aimed to examine the attitudes of a sample of Saudi college students towards the effect of listening to English songs outside class on their English competence and performance. However, one common aspect between the above study and the present study was the data collection tool which was a questionnaire.

\section{METHODS}

\section{A. Data Collection Tool}

To help provide answers to the research questions, the researcher developed a short, online questionnaire and used it to collect data from the responses of the Saudi college students participating in this study. The students were in their first year studying English in a general English course at the Community College of King Saud University in the second semester of the academic year 2020. Apparently, most of them were either 18 or 19 years old. The questionnaire consisted of eight statements on a scale of five responses. The statements were as follows:

1. I like to listen to English songs.

2. I learn new English words from listening to English songs.

3. I try to use the words I learn from English songs in my communication.

4. I feel motivated to learn English when I listen to English songs.

5. I try to write the new words I hear from songs.

6. I practice the words I hear from songs with other people.

7. I think English songs are a waste of time.

8. I think my English gets better when I learn new English songs.

There were five responses on which the statements were scaled: strongly agree, agree, strongly disagree, disagree, and not sure. The questionnaire did not include any demographical information about the participants' age, gender, nationality and belief because all the participants were Saudi male students belonging to one and the same age group and holding almost the same beliefs in a greatly homogeneous society. Due to the curfew imposed on account of the wide spread of coronavirus (COVID-19), the researcher designed the questionnaire online using Google Forms and sent the link of the questionnaire to the target participants who were 38 students. For ethical considerations, the participants in the questionnaire were not asked to provide their names, and care was taken to ensure that the 38 students did fill in the questionnaire online.

\section{B. Data Collection Procedure}

The topic of the present study required the researcher to collect data on the attitudes of Saudi college students towards the effectiveness of listening to English songs in boosting their self-learning of English as a foreign language outside class. Towards that effect, the researcher developed an online questionnaire to help find out what Saudi college students think of English songs and their effect on improving their communication with other people and their English language skills. The researcher drew on his teaching and research experience for the design of the statements and the scale of the questionnaire.

After designing the questionnaire, the researcher used Google Forms to generate an online version of the questionnaire so that the students could access it from home or anywhere using any device with access to the Internet. 
The link containing the statements of the questionnaire with five checkboxes was sent to the students via WhatsApp as the researcher was the students' teacher of an English course for which the researcher and the students had a WhatsApp group. The researcher gave the students a span of two days to fill in the questionnaire and submit it online. The questionnaire showed that 38 students responded to all the statements of the questionnaire. Since the questionnaire was developed using Google Forms, the data and their statistical representation were generated automatically, and that made it easier for the researcher to both present the data and interpret the findings.

\section{Data Analysis}

After collecting the data from the responses of the participating students to the statements of the online questionnaire, the researcher put the number and percentage of the responses to each statement according to the five-response scale in Table 1 below so that a panoramic view on the findings can be quickly taken. A detailed discussion of the findings of the present study will be given in the following section.

TABLE 1

GENERAL VIEW OF THE PARTICIPANTS' RESPONSES TO THE QUESTIONNAIRE

\begin{tabular}{|c|c|c|c|c|c|}
\hline Statement & $\begin{array}{c}\text { Strongly agree } \\
\text { (Number \& } \\
\text { Percentage) }\end{array}$ & $\begin{array}{c}\text { Agree } \\
\text { (Number \& } \\
\text { Percentage) }\end{array}$ & $\begin{array}{c}\text { Disagree } \\
\text { (Number \& } \\
\text { Percentage) }\end{array}$ & $\begin{array}{c}\text { Strongly disagree } \\
\text { (Number \& } \\
\text { Percentage) }\end{array}$ & $\begin{array}{c}\text { Not sure } \\
\text { (Number \& } \\
\text { Percentage) }\end{array}$ \\
\hline I like to listen to English songs. & $16(42.1 \%)$ & $15(39.5 \%)$ & $1(2.6 \%)$ & $1(2.6 \%)$ & $6(15.8 \%)$ \\
\hline $\begin{array}{l}\text { I learn new English words from } \\
\text { listening to English songs. }\end{array}$ & $12(31.6 \%)$ & $15(39.5 \%)$ & $3(7.9 \%)$ & $0(0 \%)$ & $10(26.3 \%)$ \\
\hline $\begin{array}{l}\text { I try to use the words I learn from } \\
\text { English songs in my communication. }\end{array}$ & $12(31.6 \%)$ & $13(34.2 \%)$ & $7(18.4 \%)$ & $0(0 \%)$ & $6(15.8 \%)$ \\
\hline $\begin{array}{l}\text { I feel motivated to learn English when } \\
\text { I listen to English songs. }\end{array}$ & $12(31.6 \%)$ & $14(36.8 \%)$ & $6(15.8 \%)$ & $5(13.2 \%)$ & $8(21.1 \%)$ \\
\hline $\begin{array}{l}\text { I try to write the new words I hear } \\
\text { from songs. }\end{array}$ & $5(13.2 \%)$ & $12(31.6 \%)$ & $9(23.7 \%)$ & $2(5.3 \%)$ & $11(28.9 \%)$ \\
\hline $\begin{array}{l}\text { I practice the words I hear from songs } \\
\text { with other people. }\end{array}$ & $10(26.3 \%)$ & $15(39.5 \%)$ & $6(15.8 \%)$ & $2(5.3 \%)$ & $5(13.2 \%)$ \\
\hline $\begin{array}{l}\text { I think English songs are a waste of } \\
\text { time. }\end{array}$ & $4(10.5 \%)$ & $5(13.2 \%)$ & $14(36.8 \%)$ & $14(36.8 \%)$ & $2(5.3 \%)$ \\
\hline $\begin{array}{l}\text { I think my English gets better when I } \\
\text { learn new English songs. }\end{array}$ & $14(36.8 \%)$ & $20(52.6 \%)$ & $2(5.3 \%)$ & $0(0 \%)$ & $3(7.9 \%)$ \\
\hline
\end{tabular}

\section{RESULTS AND DISCUSSION}

This section provides a detailed discussion of the findings of the present study. In general, the findings provide important insights into the effect of listening to English songs on the Saudi students' self-learning of English as a foreign language and the English language skills sharpened by listening to English songs. For practical reasons, the researcher will present and discuss each of the eight statements of the questionnaire along with the relevant findings in a distinct figure or bar graph.

By looking at Figure 3.1 below, we can see the first statement of the questionnaire 'I like to listen to English songs', and right underneath it we see 38 responses representing the total number of the Saudi students who took part in the study and responded to the online questionnaire. In fact, the figure reveals the findings of the present study on the first statement. So, those who strongly agreed with the statement represented $42.1 \%$, those who only agreed with the statement represented $39.5 \%$, while those who disagreed represented $2.6 \%$, those who strongly disagreed represented $2.6 \%$ and finally $15.8 \%$ were not sure whether they liked English songs or not. Roughly speaking, $81.6 \%$ of the Saudi students surveyed seemed to like English songs. This is a very high percentage indeed and a finding worth reporting. It can also be inferred from this finding that listening to English songs has a positive effect on the students' learning of English. That is why they like it. So, this significant finding forms a broad answer to the first research question and contributes to realizing the first objective of the present study. 


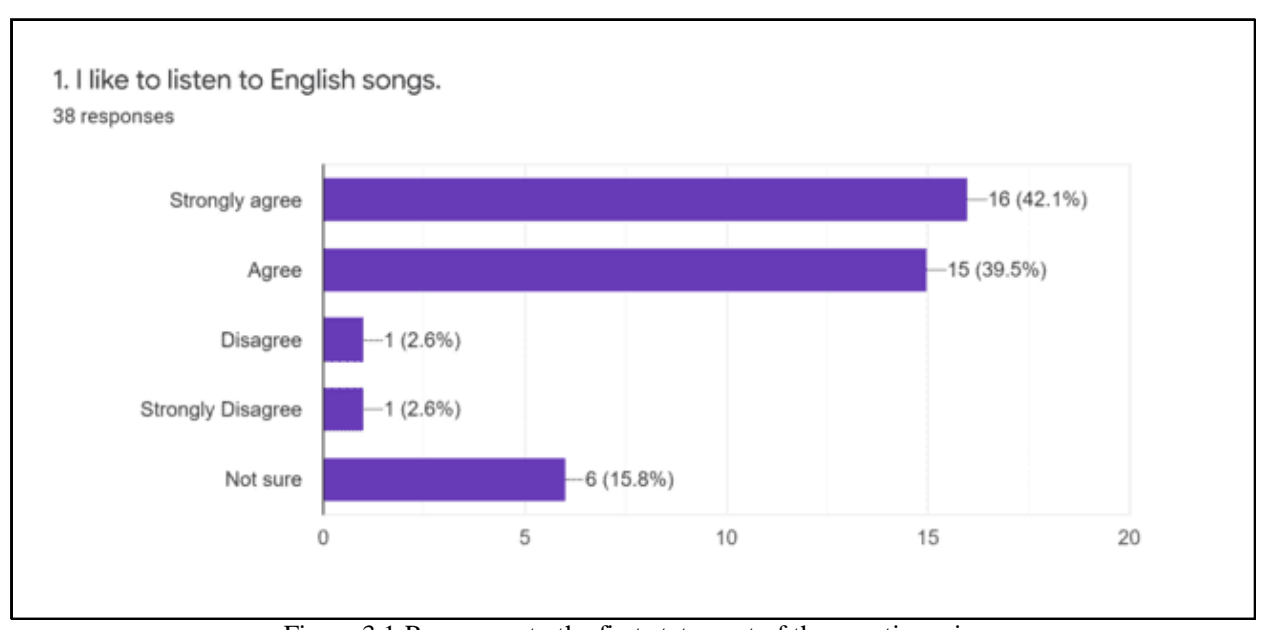

Figure 3.1 Responses to the first statement of the questionnaire

As for the second statement of the questionnaire 'I learn new English words from listening to English songs', Figure 3.2 below shows that $31.6 \%$ of the students surveyed strongly agreed with it, and $39.5 \%$ only agreed with it. However, $7.9 \%$ disagreed with the statement, and no one strongly disagreed with it, while $26.3 \%$ were not sure whether they learn new English words from listening to English songs or not. In other words, $71 \%$ of the Saudi students who responded to this statement agreed that they learn new English words from listening to songs. This is a very important finding, and it relates to the development of the students' vocabulary skill as a direct result of listening to English songs. This finding also provides part of an answer to one of the research questions related to the skills honed through listening to English songs and helps realize one of the study's objectives related to identifying skills as a result of listening to English songs.

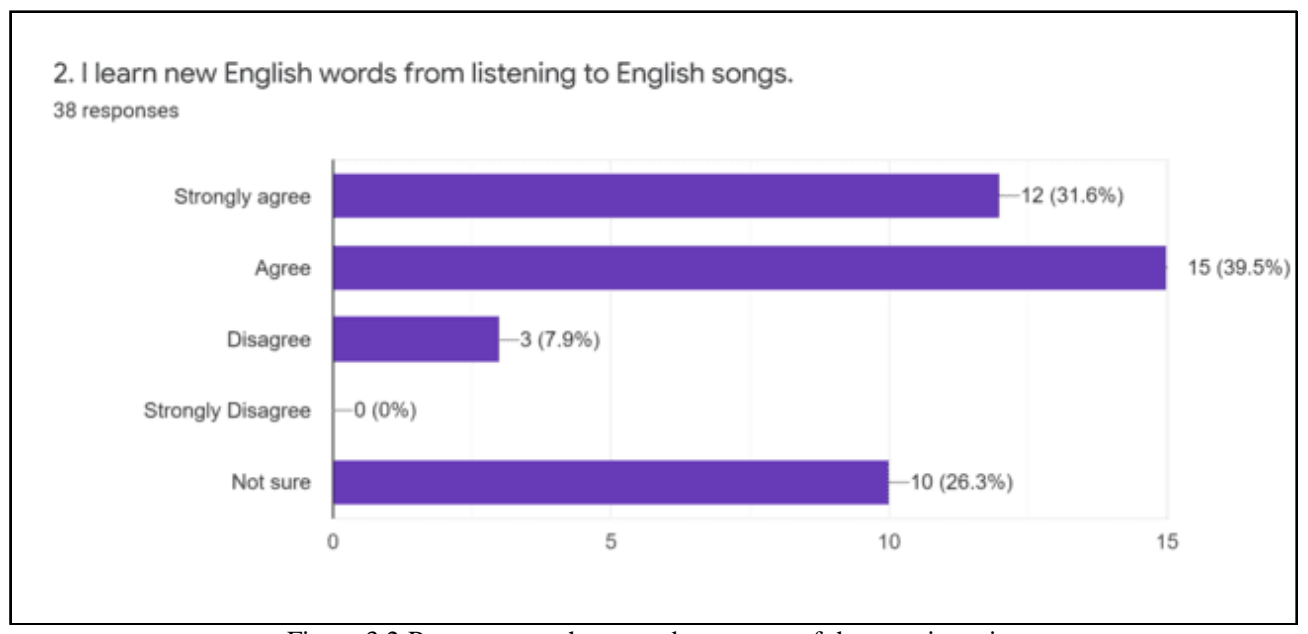

Figure 3.2 Responses to the second statement of the questionnaire

As for the third statement of the questionnaire 'I try to use the words I learn from English songs in my communication', Figure 3.3. below shows that $31.6 \%$ of the Saudi students who responded to this statement strongly agreed with it, and $34.2 \%$ only agreed with it. However, $18.4 \%$ just disagreed with the statement, and no one strongly disagreed with it. In addition, $15.8 \%$ were not sure whether they agreed or disagreed with the statement. Based on these findings, it is obvious that $65.8 \%$ of the Saudi students try to use the words they learn from listening to English songs in their communication with other people. This means that the students' self-learning strategy of listening to English songs impacts their vocabulary acquisition greatly and improves their communication skills in English. Moreover, this finding provides part of an answer to the research question related to the skills honed through listening to English songs and helps realize one of the study's objectives related to identifying skills as a result of listening to English songs. 


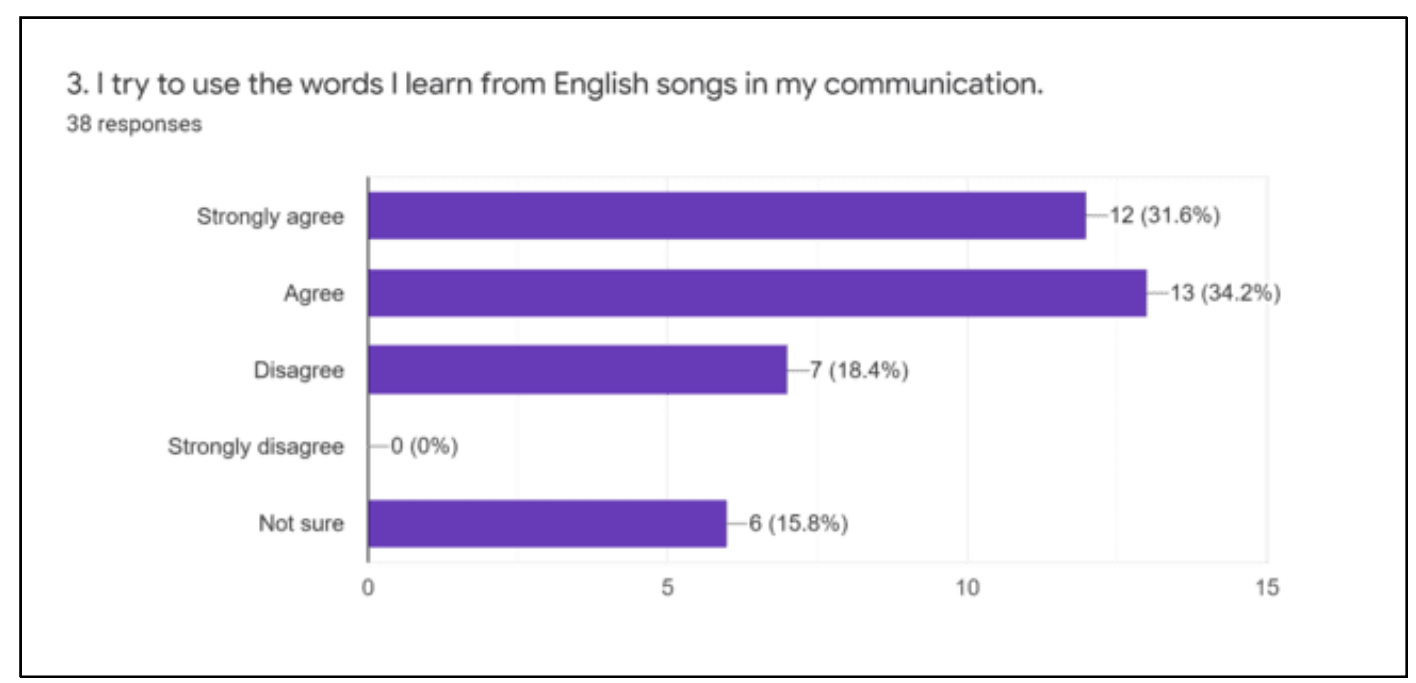

Figure 3.3 Responses to the third statement of the questionnaire

With regard to the fourth statement of the questionnaire 'I feel motivated to learn English when I listen to English songs', Figure 3.4 below shows that $31.6 \%$ of the Saudi students surveyed strongly agreed that they feel motivated to learn English when they listen to English songs, and 36.8\% agreed with the statement. However, $15.8 \%$ disagreed with the statement, and $13.2 \%$ strongly disagreed with the statement. Moreover, $21.1 \%$ were not sure whether they had to agree or disagree with the statement. The interesting finding here is that most of the students surveyed (68.4\%) agreed that listening to English songs motivated them to learn English. In other words, listening to English songs boosts students' self-learning of English as a foreign language. This finding provides an answer to the first research question related to the effect which listening to English songs has on the students' self-learning of English as a foreign language. The finding also contributes to realizing the first research question of the present study.

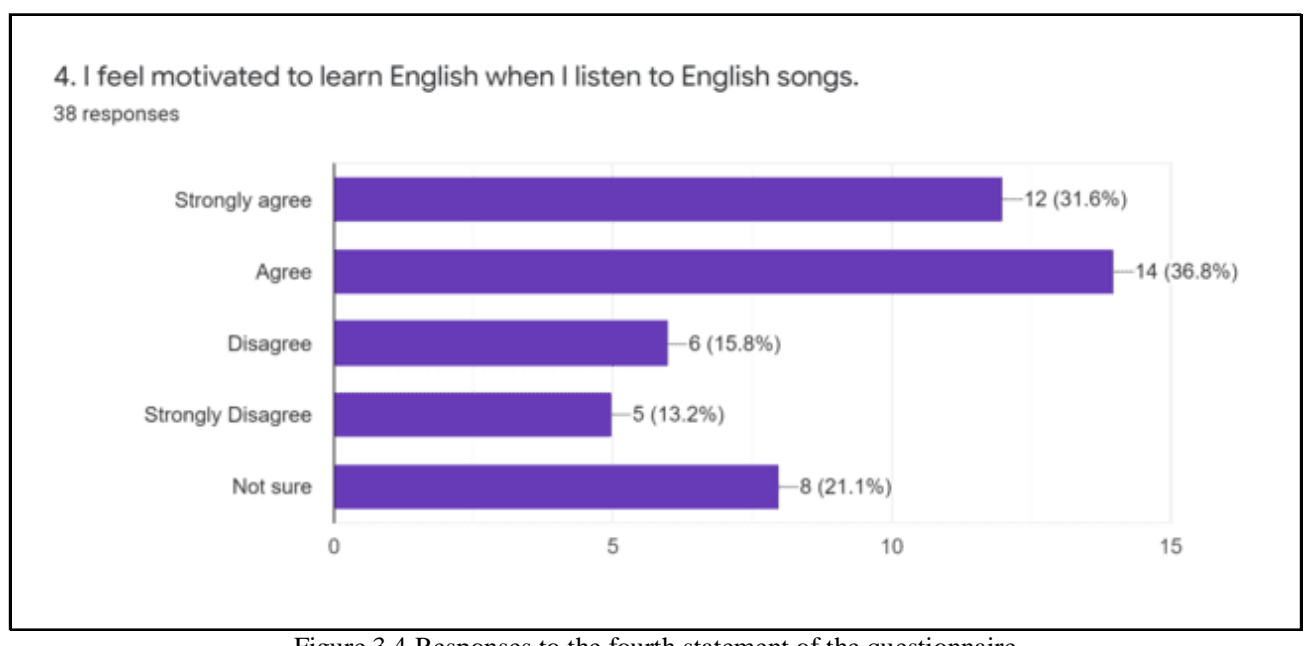

Figure 3.4 Responses to the fourth statement of the questionnaire

As regards the fifth statement of the questionnaire 'I try to write the new words I hear from songs' which is related to the writing or spelling skill, Figure 3.5 below shows that $13.2 \%$ of the Saudi students who responded to the questionnaire strongly agreed with the statement, and $31.6 \%$ only agreed with it. In other words, less than half of the students surveyed, i.e., $44.8 \%$, said that they would try to write the new words they would hear from songs. This finding is statistically significant because it tells about the difficulty of the writing skill in English compared to the other skills such as vocabulary, speaking and listening. The finding also forms part of the answer to the research question related to developing English language skills. In this case, the skill which listening to English songs improves for this percentage of the students is writing or spelling. Figure 3.5 below also shows that $23.7 \%$ of the Saudi students disagreed with the statement and $5.3 \%$ strongly disagreed with it. So, those who disagreed with the statement represented $29 \%$ of the total respondents, which is not a high percentage compared to those who agreed with the statement. Finally, 28.9\% were not sure whether to agree or disagree with the statement, or perhaps they would not try to write the new words they would hear from English songs; they would just enjoy listening to songs! 


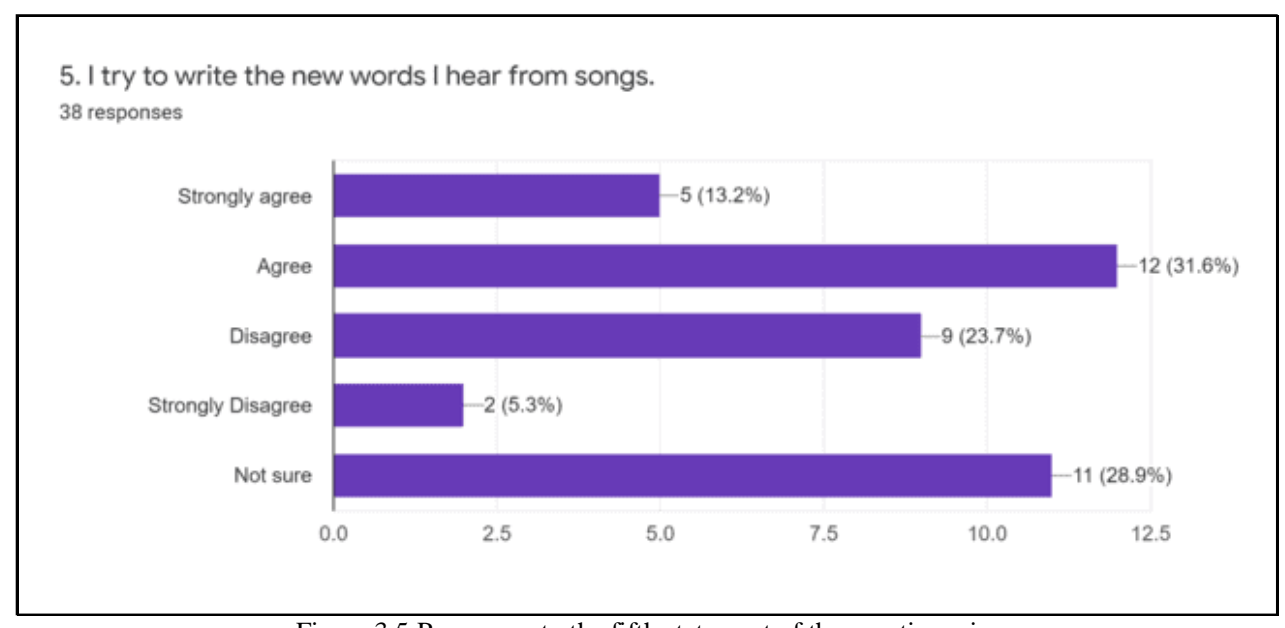

Figure 3.5 Responses to the fifth statement of the questionnaire

With regard to the sixth statement of the questionnaire 'I practice the words I hear from songs with other people', Figure 3.6 below shows that $26.3 \%$ of the Saudi participants strongly agreed with it, and $39.5 \%$ agreed with it. This means that in total $65.8 \%$ do practice the words they hear from English songs with their friends, family members or other people. This finding is important as it contributes to answering the first question of the present study which is related to the effect which listening to English songs has on the Saudi students' self-learning of English as a foreign language. In this case, the majority of the students admitted that listening to English songs not only influenced them positively, but they also used the words in the songs in their communication with other people. The finding is also related to answering the second research question which has to do with the skill which listening to English songs helps improve. In this case, it is the speaking or communication skill which the Saudi students feel listening to English songs improves. Moreover, the finding contributes to realizing the first and second objectives of the present study.

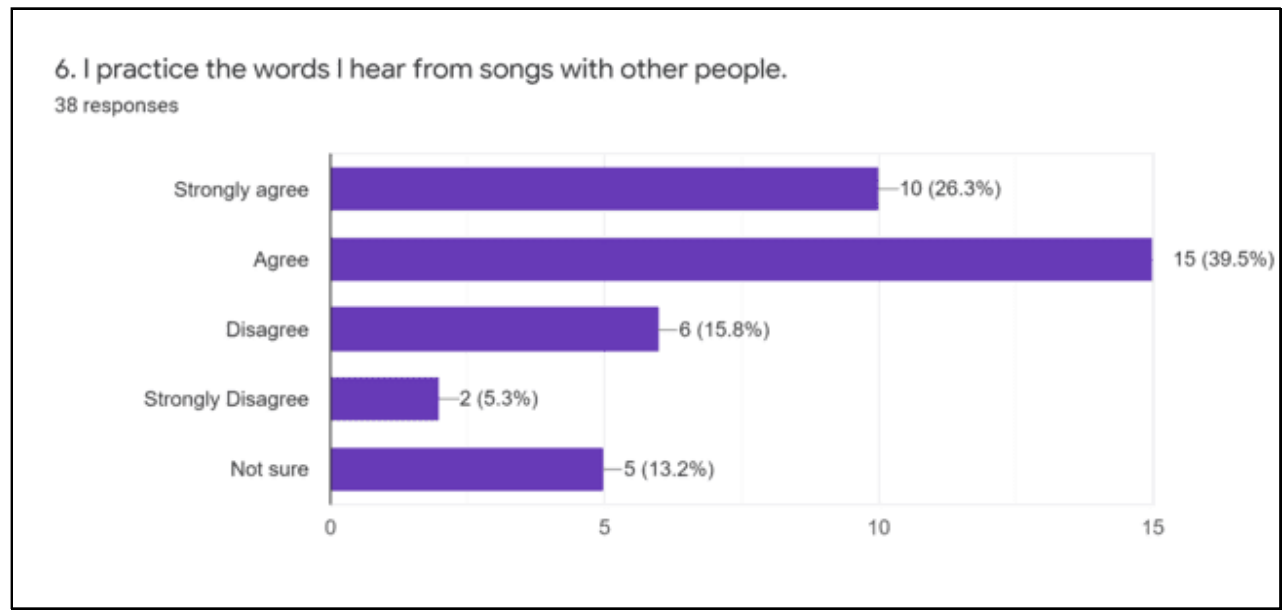

Figure 3.6 Responses to the sixth statement of the questionnaire

With regard to the seventh statement of the questionnaire 'I think English songs are a waste of time', Figure 3.7 below shows that $10.5 \%$ of the Saudi students surveyed strongly agreed with it and $13.2 \%$ only agreed with it. This means that on average $23.7 \%$ of the participants thought that listening to English songs was a waste of time for them or did not have a good effect on them, while $36.8 \%$ disagreed with that statement and $36.8 \%$ strongly disagreed with it, too. In other words, $73.6 \%$ of the Saudi students surveyed believed that listening to English songs was not a waste of time. This clearly implies that listening to English songs, for the majority of the Saudi students of the present study, has a positive or good effect on them and their learning of English on their own and outside class. This finding is quite significant as it contributes to answering the first question of the present study which is related to the effect which listening to English songs has on the Saudi students' self-learning of English. In addition, the finding contributes to realizing the first and third objectives of the present study. Last but not least, only $5.3 \%$ of the students were not sure whether listening to English songs was really a waste of time or not. 


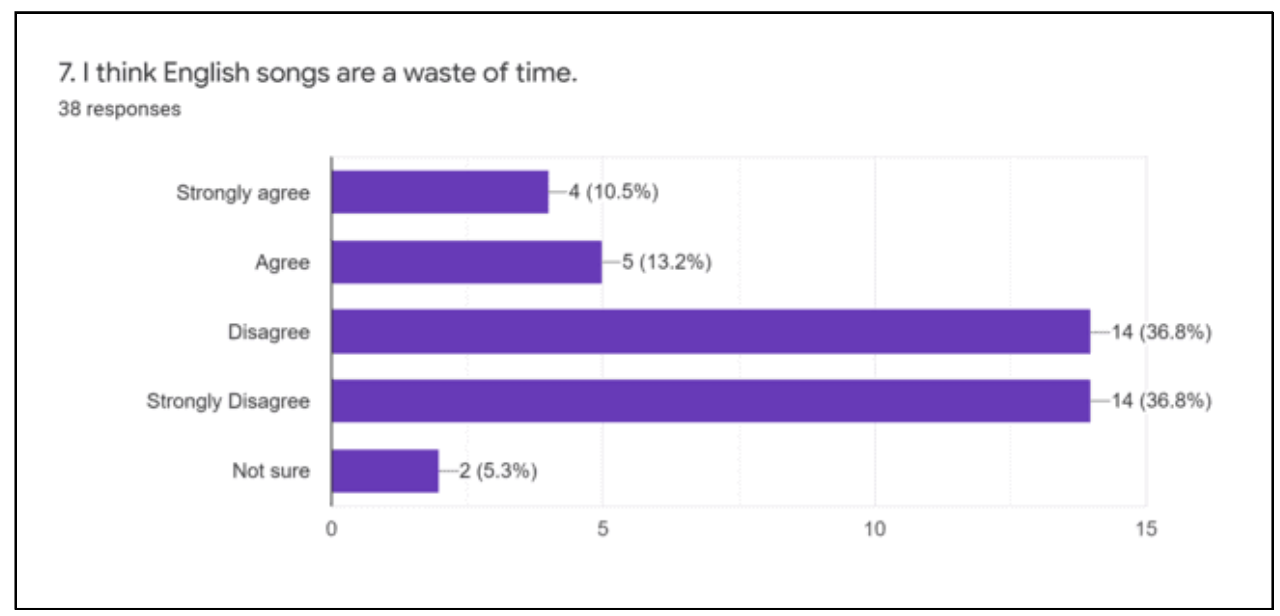

Figure 3.7 Responses to the seventh statement of the questionnaire

As regards the eighth and last statement of the questionnaire 'I think my English gets better when I learn new English songs', figure 3.8 below shows that $36.8 \%$ of the Saudi students who responded to the questionnaire strongly agreed with it, and $52.6 \%$ only agreed with it. In other words, $89.4 \%$ of the students believed that their English improved when they listened to new English songs. This is a striking finding which not only confirms that listening to English songs has a positive effect of the Saudi students' self-learning of English, but it also shows that listening to English songs improves the students' English language skills in general. In fact, this important finding does indeed contribute to answering all the research questions and realizing all of its objectives because it is not only related to the effect of English songs on the Saudi students' self-learning of English and the skills improved by it, but it also provides the field of teaching English as a foreign language (TEFL/EFL) with revealing insights into self-learning of English as a foreign language through English songs. Figure 3.8 also shows that only 5.35\% of the Saudi students surveyed in the questionnaire disagreed with the eighth statement, while no single student strongly disagreed with it. This means that only a very small number of the students of the present study thought that their English did not improve when they learned new English songs. Finally, 3.9\% of the students were not sure whether to agree or disagree with the statement.

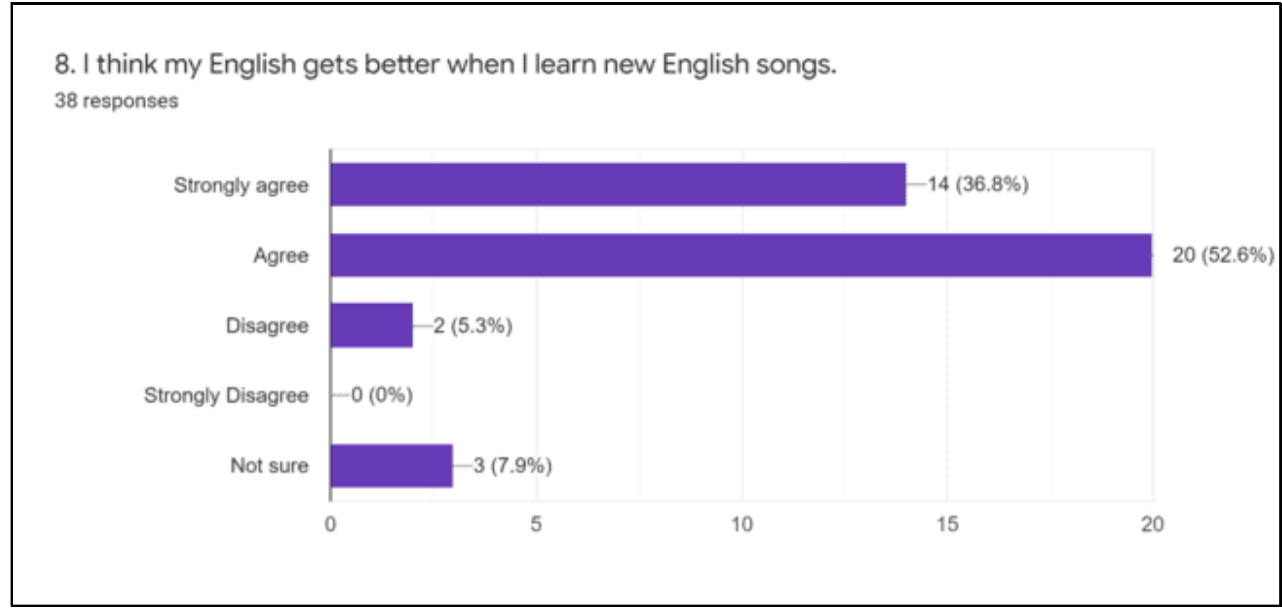

Figure 3.8 Responses to the eighth statement of the questionnaire

\section{CONCLUSION}

The present study has investigated the role of English songs in Saudi students' self-learning of English as a foreign language, and has shown that listening to English songs has a positive effect on the Saudi students' self-learning of English as a foreign language. Besides, the responses of the participants in the study have also revealed that the majority of the sample surveyed like to listen to English songs in their free time outside class, learn new words from listening to English songs, use the words they learn from English songs in their communication with other people, feel motivated to learn English by virtue of listening to English songs, think that listening to English songs is not a waste of time and last but not least feel that their English becomes better when they listen to English songs. Only less than half of the students who responded to the questionnaire said they would try to write the new words of the songs they listen to. In other words, the findings of the present study on the role of English songs in Saudi students' self-learning of English indicate that listening to English songs motivates students to learn English in a self-study mode, augments students' vocabulary, improves their speaking skill and, to a considerable extent, develops their spelling or writing skill. 
Based on the findings of the study, the researcher suggests that more large-scale quantitative or qualitative studies on the role of English songs in Saudi students' self-learning of English as a foreign language be conducted to confirm the findings of the present study, challenge them or yield new ones. It is also hoped that the topic and findings of the present study will pique the interest of EFL scholars and academics to conduct similar research on EFL students, other than Saudi students, and see if similar or different findings can be arrived at.

\section{APPENDIX. THE QUESTIONNAIRE}

Please tick $(\sqrt{ })$ the response that applies to you. There are no true or false answers, so it is important that your answers are about what you think. Your answers will be treated confidentially.

\begin{tabular}{|l|l|l|l|l|}
\hline \multicolumn{1}{|c|}{ Statement } & Strongly agree & Agree & Disagree & Strongly disagree \\
\hline I like to listen to English songs. & & & & \\
\hline $\begin{array}{l}\text { I learn new English words from listening } \\
\text { to English songs. }\end{array}$ & & & & \\
\hline $\begin{array}{l}\text { I try to use the words I learn from } \\
\text { English songs in my communication. }\end{array}$ & & & & \\
\hline $\begin{array}{l}\text { I feel motivated to learn English when I } \\
\text { listen to English songs. }\end{array}$ & & & & \\
\hline $\begin{array}{l}\text { I try to write the new words I hear from } \\
\text { songs. }\end{array}$ & & & & \\
\hline $\begin{array}{l}\text { I practice the words I hear from songs } \\
\text { with other people. }\end{array}$ & & & & \\
\hline I think English songs are a waste of time. & & & & \\
\hline $\begin{array}{l}\text { I think my English gets better when I } \\
\text { learn new English songs. }\end{array}$ & & & & \\
\hline
\end{tabular}

\section{REFERENCES}

[1] Alherbi, H. (2015). Improving students' English speaking proficiency in Saudi public schools. International Journal of Instruction, 8(1), 105-116.

[2] Almutairi, M., and Nadia, S. (2016). Using Songs in Teaching Oral Skills to Young Learners: Teachers' Views and Attitudes. International Journal of Linguistics, 8 (6), 133 - 153.

[3] Dzanic, Nihada. D., and Alisa, P. (2016). The Effect of Using Songs On Young Learners and Their Motivation for Learning English. New Trends in Social and Liberal Sciences: An Interdisciplinary Journal, 1 (2), 40 - 54.

[4] Fras, P., \& Polona, F. (2015). Using songs in class: A case study. Shoin ELTC Forum, 4, 47-53.

[5] Hindeme, U.O.S., Pedro, M.E., and Evariste, K. (2018). The roles of songs in teaching English to EFL beginner learners: the case of some secondary schools in Benin Republic. Revue Internationale de Linguistique Appliquée, de Littérature et d'Education, 1(1), $281-301$.

[6] Holbah, W. A. (2015). Motivation for learning English in the Saudi Arabian context: Perceptions of learners, teachers and parents. Doctorate Thesis. Unpublished. Australia: Flinders University.

[7] Ilham, K. K. (2009). "The effectiveness of teaching vocabulary using songs and hand puppets: An experimental study at the fourth years of SD Negeri Gentan 02 Baki, Sokoharjo”. Diss. School of Teacher Training and Education Muhammadiyah University of Surakarta.

[8] Israel, H. F. (2013). Language Learning Enhanced by Music and Song. Literacy Information and Computer Education Journal (LICEJ), Special Issue, 2 (1), 1360-1366.

[9] Javadi-Safa, Azim. (2018). Effects of Using Songs on Adult EFL Learners' Vocabulary Learning. Journal of Applied Linguistics and Language Research, 5 (3), 101-112.

[10] Keskin, F. (2011). Using songs as audio materials in teaching Turkish as a foreign language. Turkish Online Journal of Educational Technology, 10(4), 378-383.

[11] Komur, S., Sarac, G., and Seker, H. (2005). TEACHING ENGLISH THROUGH SONGS (Practice in Muğla/TURKEY). Journal of Social Sciences and Humanities Researches, 15, $109-120$.

[12] Kurt AA, Gunuc S, Ersoy M 2013. The current state of digitalization: Digital Native, Digital Immigrant and Digital Settler. Ankara University Journal of Faculty of Educational Sciences (JFES), 46 (1), 1-22.

[13] Kusnierek, A. (2016). The role of music and songs in teaching English vocabulary to students. World Scientific News, 43 (1), 1 -55 .

[14] Murray, K.J. (2005). Learning a Second Language through Music, Baylor University, Academic Exchange Quarterly, 9 (2), 161-165.

[15] Sad, S. N., \& Ozlem Goktas. (2014). Preservice teachers' perceptions about using mobile phones and laptops in education as mobile learning tools. British Journal of Educational Technology, 45(4), 606 - 618.

[16] Sargsyan, M., \& Kurghinyan, A. (2016). The use of English language outside the classroom. Journal of Language and Cultural Education, 4(1), 29-47.

[17] Siskova, D. (2008). Teaching vocabulary through music. Diss. Masaryk U in Brono.

[18] Tarrant, M. (2002). Adolescent peer groups and social identity. Social Development, 11, 110-123.

[19] Toffoli, D., and Geoffrey Sockett. (2014). English language music: Does it help with learning? Recherche et Pratiques Pédagogiques en Langues de Spécialité: Cahiers de l'APLIUT, Association des Professeurs de Langues des IUT (APLIUT), 2014, Pratiques émergentes et recherches en didactique de l'anglais: jalons, interrogations et perspectives, Vol. XXXIII (2), 
pp.192-209.10.4000/apliut.4450. hal-01227563.

[20] Vishnevskaia, M and Zhou, Z. (2019). The Impact of Using Music and Songs on Teaching EFL in China by Non-native English Teachers. Universal Journal of Educational Research, 7(8), 1808-1813

[21] Wu, C. L. (2015). Digital Natives and Digital Immigrants in Anti-Nuclear Campaign: From Media and Technology Usage and Citizen Participation Perspectives. Master Thesis, Unpublished. Taiwan: National Sun Yat-Sen University.

[22] Yong, S., and Gates. P. (2014). Born digital: Are they really digital natives? International Journal of e-Education, 4, $102-105$.

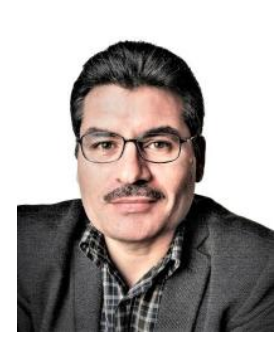

Omar Jabak was born in Syria in 1973. He earned his BA in the English Language and Literature from Aleppo University in 1995. He did a postgraduate diploma in literary studies at Aleppo University in 1996. He did his MA in translation at the University of Salford in the UK. He did his PhD in Translation and Interpretation at Universiti Putra Malaysia in 2018.

$\mathrm{He}$ is currently working at the Department of Foreign Languages, College of Arts and Sciences at University of Nizwa in Oman as Assistant Professor in Translation. His main research interests include translation studies, translation practice, English-Arabic and Arabic-English translation, cultural studies, applied linguistics and EFL. He has translated some English books (fiction and non-fiction) into Arabic. He has also published some books and articles on translation and EFL.

Dr. Jabak is a reviewer for a number of international journals such as International Journal of English and Literature, International Journal of Literature, Language and Linguistics, Asian Research of Arts and Social Sciences, AWEJ for translation \& Literary Studies, Issues in Language Studies, SAGE Open and others. He received three grants from King Saud University for translating two reference books and publishing one research article. 